University of Nebraska - Lincoln

DigitalCommons@University of Nebraska - Lincoln

2006

\title{
Widespread Presence of Naturally Occurring Perchlorate in High Plains of Texas and New Mexico
}

Srinath Rajagopalan

Todd Anderson

Lynne Fahlquist

U.S. Geological Survey

Ken Rainwater

Moira Ridley

See next page for additional authors

Follow this and additional works at: https://digitalcommons.unl.edu/usgsstaffpub

Part of the Earth Sciences Commons

Rajagopalan, Srinath; Anderson, Todd; Fahlquist, Lynne; Rainwater, Ken; Ridley, Moira; and Jackson, W. Andrew, "Widespread Presence of Naturally Occurring Perchlorate in High Plains of Texas and New Mexico" (2006). USGS Staff -- Published Research. 78.

https://digitalcommons.unl.edu/usgsstaffpub/78

This Article is brought to you for free and open access by the US Geological Survey at DigitalCommons@University of Nebraska - Lincoln. It has been accepted for inclusion in USGS Staff -- Published Research by an authorized administrator of DigitalCommons@University of Nebraska - Lincoln. 


\section{Authors}

Srinath Rajagopalan, Todd Anderson, Lynne Fahlquist, Ken Rainwater, Moira Ridley, and W. Andrew Jackson 


\section{Widespread Presence of Naturally Occurring Perchlorate in High Plains of Texas and New Mexico}

\author{
SRINATH RAJAGOPALAN, ${ }^{\dagger}$ \\ TODD A. ANDERSON, \\ LYNNE FAHLQUIST, $\$$ \\ KEN A. RAINWATER, ${ }^{\dagger}$ \\ MOIRA RIDLEY, $\perp$ AND \\ W. A N DREW JACKSON*, \\ Department of Civil Engineering, Texas Tech University, \\ Lubbock, Texas 79409-1023, The Institute of Environmental \\ and Human Health, Texas Tech University, Lubbock, Texas \\ 79409-1163, U.S. Geological Survey, 8027 Exchange Dr, \\ Austin, Texas 78754, and Department of Geosciences, \\ Texas Tech University, Lubbock, Texas 79409-1053
}

Perchlorate $\left(\mathrm{ClO}_{4}^{-}\right)$occurrence in groundwater has previously been linked to industrial releases and the historic use of Chilean nitrate fertilizers. However, recently a number of occurrences have been identified for which there is no obvious anthropogenic source. Groundwater from an area of $155000 \mathrm{~km}^{2}$ in 56 counties in northwest Texas and eastern New Mexico is impacted by the presence of $\mathrm{ClO}_{4}{ }^{-}$. Concentrations were generally low $(<4 \mathrm{ppb})$, although some areas are impacted by concentrations up to $200 \mathrm{ppb}$. $\mathrm{ClO}_{4}{ }^{-}$distribution is not related to well type (public water system, domestic, agricultural, or water-table monitoring) or aquifer (Ogallala, Edward Trinity High Plains, Edwards Trinity Plateau, Seymour, or Cenozoic). Results from vertically nested wells strongly indicate a surface source. The source of $\mathrm{ClO}_{4}{ }^{-}$appears to most likely be atmospheric deposition. Evidence supporting this hypothesis primarily relates to the presence of $\mathrm{ClO}_{4}{ }^{-}$in tritium-free older water, the lack of relation between land use and concentration distribution, the inability of potential anthropogenic sources to account for the estimated mass of $\mathrm{ClO}_{4}{ }^{-}$, and the positive relationship between conserved anions (e.g., $\mathrm{IO}_{3}{ }^{-}$, $\mathrm{Cl}^{-}, \mathrm{SO}_{4}{ }^{-2}$ ) and $\mathrm{ClO}_{4}{ }^{-}$. The $\mathrm{ClO}_{4}{ }^{-}$distribution appears to be mainly related to evaporative concentration and unsaturated transport. This process has led to higher $\mathrm{ClO}_{4}{ }^{-}$and other ion concentrations in groundwater where the water table is relatively shallow, and in areas with lower saturated thickness. Irrigation may have accelerated this process in some areas by increasing the transport of accumulated salts and by increasing the number of evaporative cycles. Results from this study highlight the potential for $\mathrm{ClO}_{4}{ }^{-}$to impact groundwater in arid and semiarid areas through long-term atmospheric deposition.

\footnotetext{
* Corresponding author phone: (806) 7422801 (230); fax: (806) 742 3449; e-mail: andrew.jackson@ttu.edu.

${ }^{\dagger}$ Department of Civil Engineering, Texas Tech University.

‡ The Institute of Environmental and Human Health, Texas Tech University.

$\S$ U.S. Geological Survey.

${ }^{\perp}$ Department of Geosciences, Texas Tech University.
}

\section{Introduction}

Since the discovery of perchlorate $\left(\mathrm{ClO}_{4}^{-}\right)$as a groundwater contaminant in California in 1997, it has become the focus of research efforts and controversy. Perchlorate salts have been widely used for decades as oxidizers in rockets and munitions, as well as in various industrial products including fireworks, electroplating products, dyes, and air bag inflators (1). As improved analytical capabilities allow measurement of $\mathrm{ClO}_{4}{ }^{-}$at lower concentrations, the frequency of detections in groundwater and surface water has steadily increased. Well-known occurrences (e.g., Lake Mead and the lower Colorado River) can be attributed to industrial or military sites, primarily associated with point sources such as munitions production and assembly areas. Lesser known occurrences of $\mathrm{ClO}_{4}{ }^{-}$could be associated with other widely used products such as fireworks, matches, gas drying applications, seismic charges, and highway safety flares. Historic use of naturally derived nitrate fertilizers mined from Chilean salt deposits, which contain $\mathrm{ClO}_{4}^{-}$, also could introduce it into agricultural environments. Natural sources of $\mathrm{ClO}_{4}^{-}$other than Chilean nitrate have not been widely considered in exposure assessments.

The possibility that $\mathrm{ClO}_{4}{ }^{-}$contamination of surface and groundwater may have multiple origins (military, industrial, agricultural, or natural) complicates site characterization and efforts to assign responsibility for remediation. Other complications arise when assessing potential human exposure to $\mathrm{ClO}_{4}^{-}$, especially if affected waters are used for drinking, livestock, or irrigation of food crops. For example, human exposure to $\mathrm{ClO}_{4}^{-}$has been documented in vegetation that was irrigated with water containing $\mathrm{ClO}_{4}{ }^{-}(2,3)$ and in dairy milk (4). The concern for human exposure to $\mathrm{ClO}_{4}{ }^{-}$stems from its adverse effect on developing organisms through decreased levels of thyroid hormones (T3 and T4). Perchlorate competes with iodide uptake into thyroid hormones (5) and this inhibition has been the basis of a reference dose (Rfd) set by the U.S. Environmental Protection Agency $(0.7 \mu \mathrm{g} /$ $\mathrm{kg} /$ day) and current action levels for drinking water (e.g., 1 ppb, State of Massachusetts; 4 ppb, State of Oregon; and 6 ppb, State of California).

Naturally occurring $\mathrm{ClO}_{4}^{-}$from the Atacama is widely known (6). The Atacama Desert nitrate deposits of northern Chile also contain naturally occurring $\mathrm{ClO}_{4}{ }^{-}$and other oxyanions such as $\mathrm{IO}_{3}{ }^{-}, \mathrm{CrO}_{4}{ }^{2-}$, and $\mathrm{Cr}_{2} \mathrm{O}_{7}{ }^{2-}$. $\mathrm{NO}_{3}{ }^{-}, \mathrm{IO}^{-}$, and $\mathrm{Cl}^{-}$are known to form and accumulate under arid conditions (7-9). Until recently, the well-documented Chilean deposits were believed to be the only occurrence of natural $\mathrm{ClO}_{4}{ }^{-}$. Recent studies that examined the $\Delta^{17} \mathrm{O}$ of Chilean $\mathrm{ClO}_{4}{ }^{-}{ }^{-}(10)$ or $\mathrm{NO}_{3}{ }^{-}$and $\mathrm{SO}_{4}{ }^{2-}$ (8) from these deposits indicate an atmospheric origin. $\mathrm{ClO}_{4}{ }^{-}$has been reported in atmospheric aerosols (11) and precipitation (12). Other reports of natural $\mathrm{ClO}_{4}{ }^{-}$occurrences in the U.S. include a nitrate deposit in California (13) and potash minerals and other evaporites from California and New Mexico (14). A relatively large areal distribution of $\mathrm{ClO}_{4}{ }^{-}$in west Texas groundwater (15) and groundwater, surface water, and bottled water from other areas (16) has been tentatively attributed to natural sources as well as $\mathrm{ClO}_{4}{ }^{-}$in Pleistocene and Holocene groundwater in New Mexico (17).

This study was designed to evaluate the potential source and occurrence of $\mathrm{ClO}_{4}^{-}$in West Texas. Previous studies described $\mathrm{ClO}_{4}{ }^{-}$in public water systems (PWS) and other wells in nine counties $\left(23960 \mathrm{~km}^{2}\right)$ of the southern high plains of Texas (15) in which $\mathrm{ClO}_{4}^{-}$was generally ubiquitous in groundwater and no correlation between $\mathrm{ClO}_{4}^{-}$presence and 
A

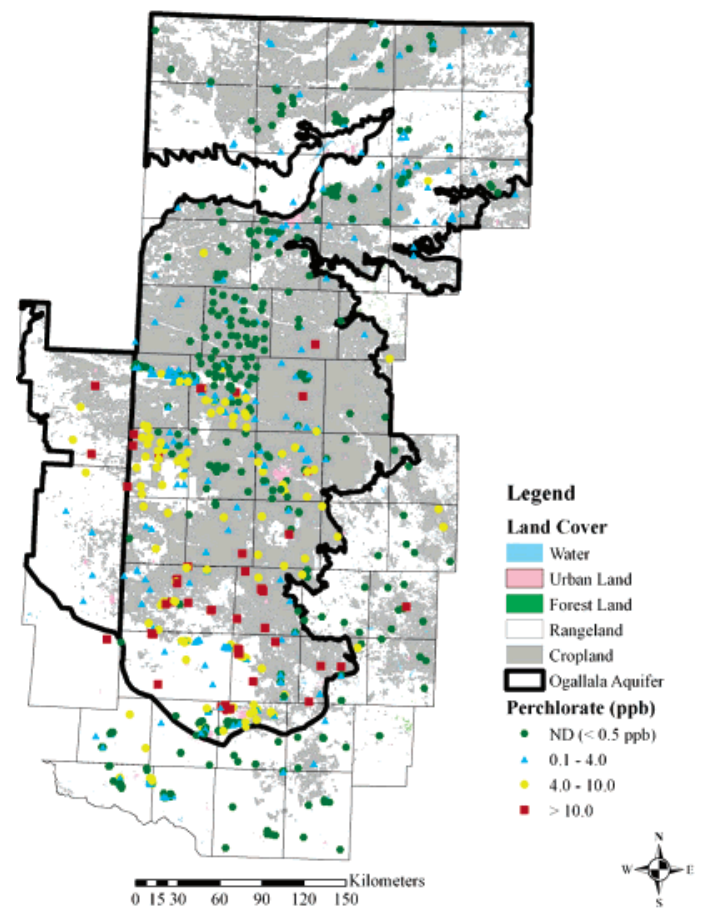

C

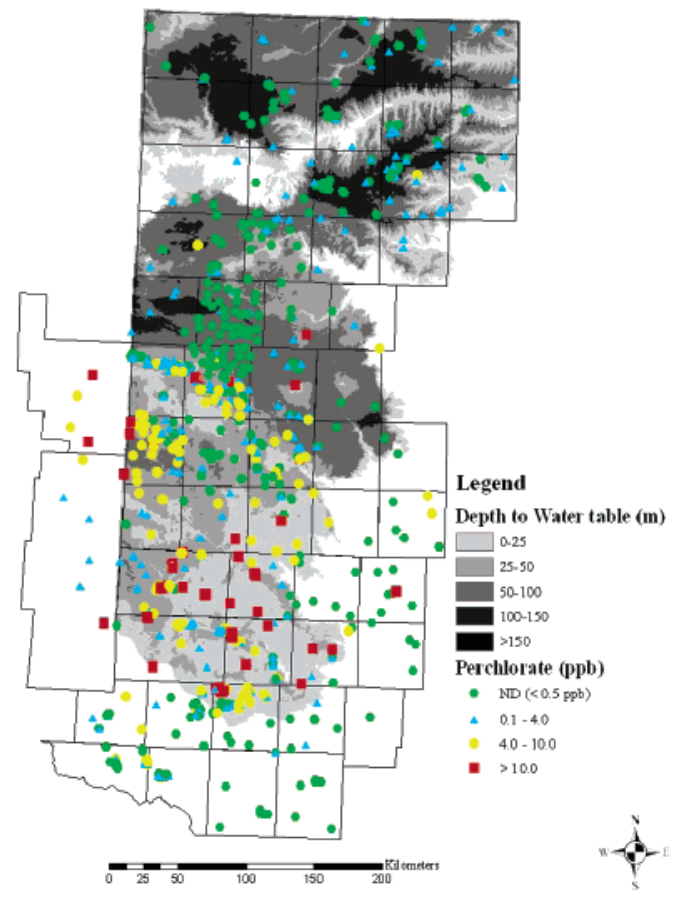

B

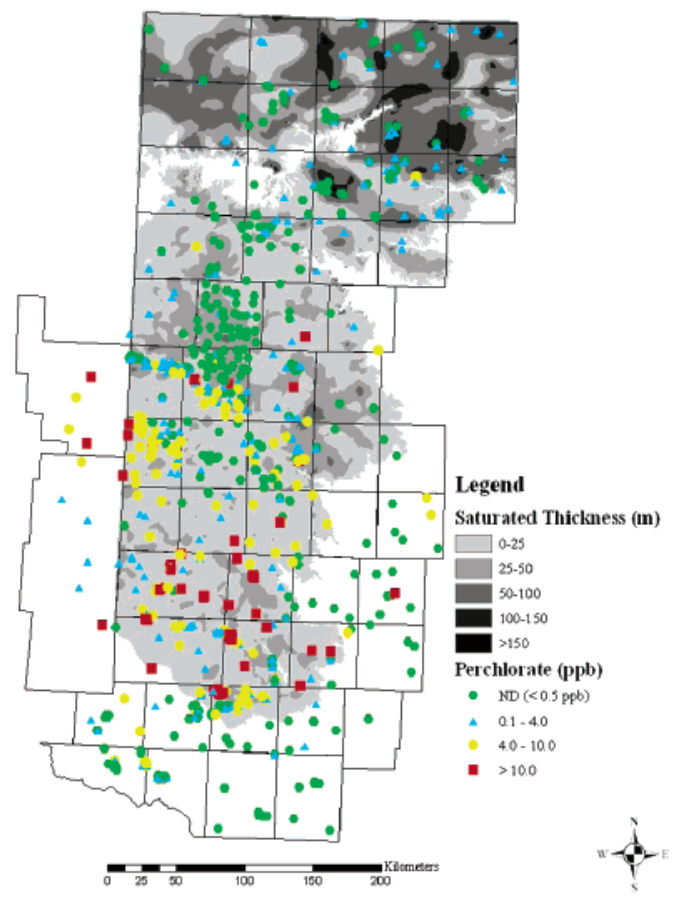

$\mathbf{C}$

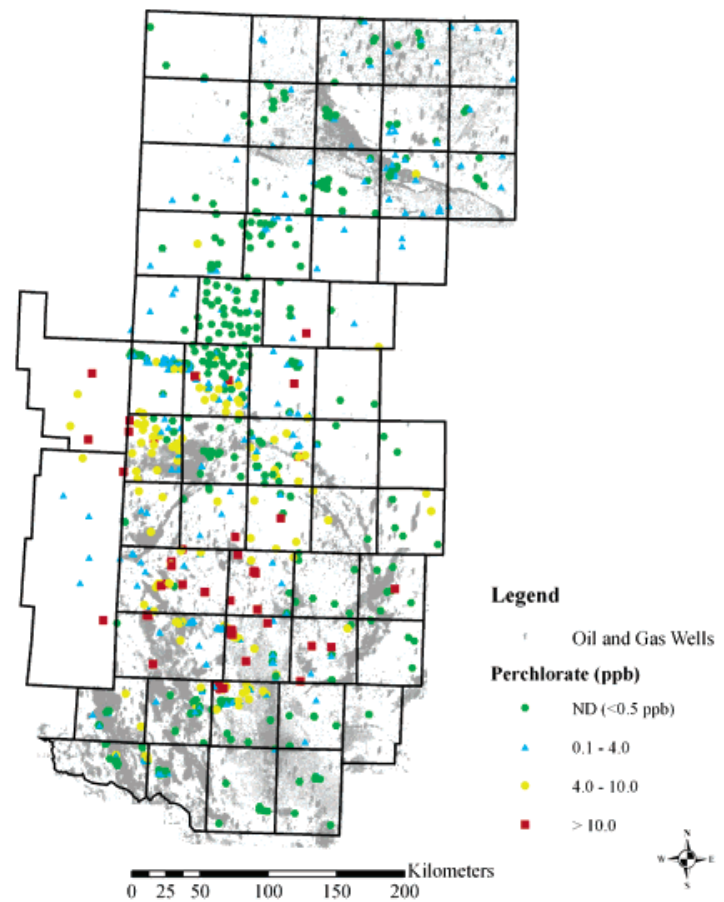

FIGURE 1. Distribution of $\mathrm{ClO}_{4}^{-}$concentration relative to (A) land use in the study area (20) and (B) saturated thickness in 0 gallala aquifer (29) (C) depth to water table in Ogallala aquifer (29) (D) active oil and gas wells in the study area (22).

human sources could be established. The study area was expanded to include 54 counties in west Texas and two counties in eastern New Mexico (see Figure A, Supporting Information), covering an area of $153000 \mathrm{~km}^{2} . \mathrm{ClO}_{4}^{-}$ concentrations and potential sources were evaluated with respect to land uses, aquifer conditions, and other water quality parameters.

Study Area. Population in the study area is about one million, with about $50 \%$ of the population living in three major metropolitan areas, Lubbock, Odessa-Midland, and Amarillo $(18,19)$. As shown in Figure 1A, major land uses in this region are cultivation and rangelands (20). About $34 \%$ of the study area is cultivated farmland and about $1 \%$ is urban. Most of the land use (63\%) is rangeland and pastures, and the rest (2\%) is barren, forest, or open water. Large-scale farming in the study area began around the 1930s and irrigated agriculture (21) accelerated after World War II. The cultivated farmland in the study area is approximately $2.67 \%$ 
of the total farmland in the United States and is of similar extent to the farmland in California from 1930 to 1980 (21). Oil and gas exploration has occurred throughout the study area (22), with most concentrated exploitation in locations shown in Figure 1D. Two $\mathrm{ClO}_{4}{ }^{-}$processors or users are present in or near the study area and include the Pantex plant and Melrose Air Force Base (See Figure A, Supporting Information).

Major and minor aquifers are present within the study area (See Figure A, Supporting Information). The Tertiary Ogallala and Cretaceous Edwards-Trinity (Plateau and High Plains) aquifers are the principal aquifer systems (see Supporting Information for a more detailed description). Minor aquifers include Cenozoic Pecos Alluvium, Dockum, and Seymour, and are of limited extent or exploited to a lesser degree in this region (23). The study area is semi-arid with average annual precipitation ranging from $0.25 \mathrm{~m}$ in the south to $0.75 \mathrm{~m}$ in the north $(24,25)$.

Approach. Wells Sampled. Groundwater samples were collected from a variety of wells in the study area and analyzed for a suite of cations and anions, including $\mathrm{ClO}_{4}^{-}$. The Texas Commission on Environmental Quality (TCEQ) identified 2782 PWS wells in 356 PWS systems in the 54 counties. Examples of PWS wells include those for cities, mobile home parks, rural convenience stores, and industrial facilities. A subset of 560 (20\%) PWS wells were selected to provide adequate areal coverage for the study. When a selected well could not be sampled, a nearby well was selected. TCEQ sampled 256 additional PWS wells in 19 counties. In addition, 76 domestic wells in 24 counties in Texas and 10 domestic wells in two New Mexico counties were sampled to further increase the areal distribution of sample locations. Water samples were also obtained from 29 U.S. Geological Survey (USGS) water table monitoring wells and 99 High Plains Underground Water Conservation District (HPUWCD) No.1 irrigation wells (See Figure A, Supporting Information).

Monitor Well Clusters. Three well clusters were installed to study the vertical distribution of $\mathrm{ClO}_{4}{ }^{-}$in the saturated zone of the study area in Bailey ( 2 wells), Gaines (3 wells), and Martin ( 3 wells) counties (Table 1). These three well clusters lie in an approximate $386 \mathrm{~km}$ north-south transect covering $65 \%$ of the length of the study area (See Figure A, Supporting Information). In addition to these well clusters, two nested well clusters installed by USGS in Hale (4 wells) and Castro (4 wells) counties were also sampled. Details of those wells are listed in Table 1.

Groundwater Sampling. Where possible, groundwater was sampled following well stabilization (monitored by flowthrough cells) to ensure representative samples. Some domestic windmill wells could not be stabilized. Field parameters measured at the time of sampling included $\mathrm{pH}$, total dissolved solids (TDS), conductivity (as conductance and specific conductance), temperature, dissolved oxygen (DO), and oxidation-reduction potential (ORP). Wells sampled by Texas Tech University (TTU) were analyzed for $\mathrm{ClO}_{4}{ }^{-}, \mathrm{Cl}^{-}, \mathrm{F}^{-}, \mathrm{Br}^{-}, \mathrm{NO}_{3}{ }^{-}, \mathrm{SO}_{4}{ }^{2-}, \mathrm{PO}_{4}{ }^{3-}$, alkalinity as $\mathrm{CaCO}_{3}$, $\mathrm{Na}^{+}, \mathrm{Mg}^{2+}, \mathrm{K}^{+}, \mathrm{Ca}^{2+}, \mathrm{Sr}^{2+}$; total Fe. 87 of the samples also were analyzed for $\mathrm{IO}_{3}{ }^{-}$. Samples from the TTUWRC nested well clusters and the USGS monitoring wells were analyzed for tritium by USGS.

Analytical Methods. Analysis of $\mathrm{ClO}_{4}{ }^{-}$followed EPA method 314.0 (26), details of which have been previously described (15). The $\mathrm{ClO}_{4}{ }^{-}$detection limit for the analytical method (MDL) was $0.5 \mathrm{ppb}$. Anions (other than $\mathrm{ClO}_{4}^{-}$- and $\mathrm{IO}_{3}{ }^{-}$) in water samples were determined following EPA method 300.0. Major cations and other metals were analyzed by inductively coupled plasma-atomic emission spectrometry (ICP-AES), details of which have been previously described (15). Iodate analysis was carried out using ionpair chromatography (HP 1100 series liquid chromatograph)

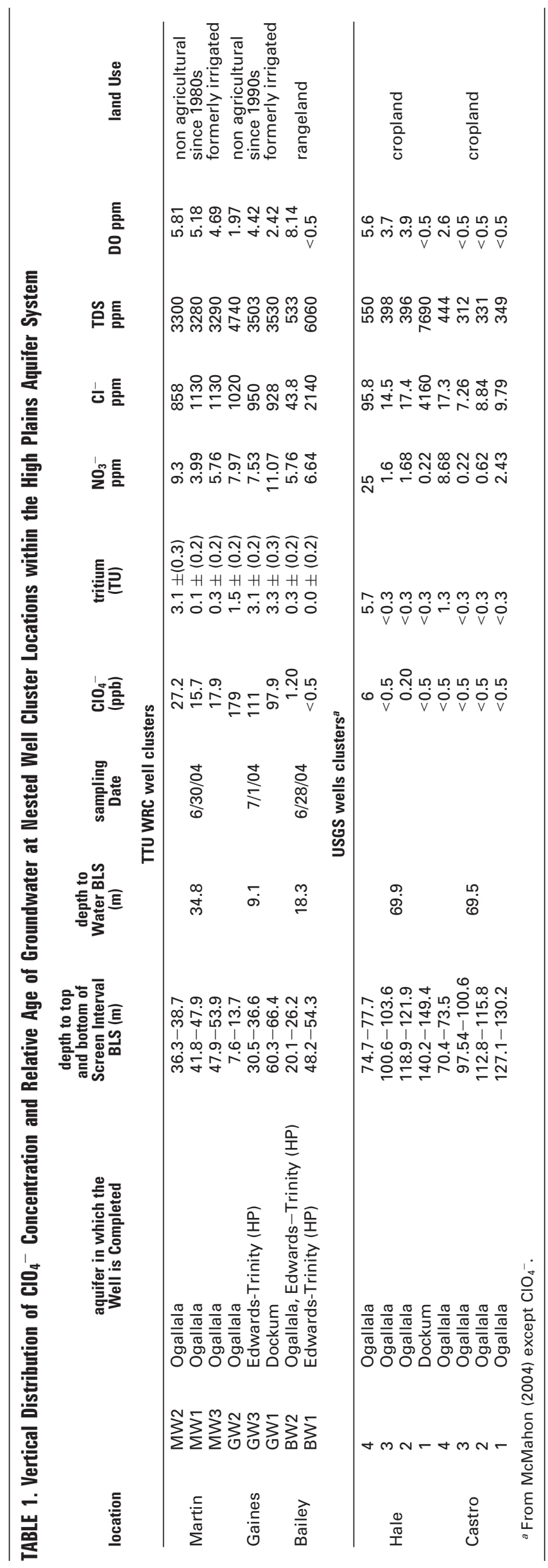


with UV detection at $214 \mathrm{~nm}$. The column was a LiChrospher $\mathrm{RP}-18(4 \mathrm{~mm} \times 125 \mathrm{~mm})$. The isocratic mobile phase was $0.01 \mathrm{M} \mathrm{KH}_{2} \mathrm{PO}_{4}$ and PIC Reagent A at $1 \mathrm{~mL} / \mathrm{min}$. This approach offered a reasonably simple technique that had the advantage of utilizing selective detection to minimize matrix interferences (chloride, sulfate) common to high salinity water samples. Tritium was analyzed at USGS by electrolytic enrichment and liquid scintillation (27).

\section{Results and Discussion}

Spatial Distribution of Perchlorate with Aquifer, Well Type, and Land Use. About one-half of the 1030 samples (wells) contained $\mathrm{ClO}_{4}{ }^{-}$at concentrations less than $0.5 \mathrm{ppb}$ (Figure 1). 115 of these samples were reanalyzed using a preconcentration method (28) that achieved a lower method detection limit of $0.1 \mathrm{ppb}$. Of the samples that were reanalyzed, 82 contained detectable $\mathrm{ClO}_{4}^{-}(>0.1 \mathrm{ppb})$. The high percentage of reanalyzed samples that tested positive for $\mathrm{ClO}_{4}{ }^{-}$at a lower method detection limit indicates that the distribution of $\mathrm{ClO}_{4}{ }^{-}$in the study area is likely a conservative estimate of its occurrence. Most of the wells sampled were aerobic, with dissolved oxygen (DO) $>2 \mathrm{mg} / \mathrm{l}$ for $95 \%$ (638) of the 675 wells for which DO was measured; under these conditions, $\mathrm{ClO}_{4}^{-}$should be stable.

The presence of $\mathrm{ClO}_{4}{ }^{-}$is widespread across the study area and concentrations are highly variable. In general, the highest concentrations were observed in the southern Ogallala aquifer with an evident abrupt change in concentration distribution above a NW-SE diagonal line approximately in the middle of the study area (Figure 1). This abrupt concentration decrease north of this line coincides with both an abrupt increase in the depth of the saturated zone and unsaturated zone north of the line (Figure 1). Perchlorate was detected $(>0.1 \mathrm{ppb})$ in $56 \%$ of the wells and in all but four counties in the study area. More than 78\% (636) of the PWS wells were completed in the Ogallala aquifer, and 398 of these contained detectable $(>0.1 \mathrm{ppb}) \mathrm{ClO}_{4}^{-}$(Figure 2 ). About $35 \%$ of PWS wells completed in aquifers other than the Ogallala contained detectable $\mathrm{ClO}_{4}{ }^{-}$, indicating that the presence of $\mathrm{ClO}_{4}{ }^{-}$is not unique to the Ogallala formation. Similar to the PWS wells, domestic wells completed in the Ogallala aquifer (84\%) more often contained $\mathrm{ClO}_{4}{ }^{-}$than wells in the other aquifers (24\%). Almost all of the irrigation wells (98), and all (29) of the USGS water-table monitoring wells were completed in the Ogallala formation. 42 of the samples from irrigation wells had detectable $\mathrm{ClO}_{4}^{-}(>0.5 \mathrm{ppb})$. The USGS water-table monitoring wells were screened at the top of the Ogallala aquifer; 20 of these wells had detectable $\mathrm{ClO}_{4}^{-}(>0.5 \mathrm{ppb}$ ) (Figure 2).

Perchlorate concentration distribution was similar between PWS, irrigation, and domestic well types, even though the wells are operationally quite different. Other than the USGS wells, only limited well construction data are available on screen lengths and depths. PWS and irrigation wells are more likely to be screened over longer intervals and at deeper depths than domestic wells. Interestingly, the USGS watertable monitoring wells, present in 10 counties, had a clearly different $\mathrm{ClO}_{4}{ }^{-}$distribution pattern and a larger percentage of wells with detectable (>0.5 ppb) $\mathrm{ClO}_{4}{ }^{-}$(Figure 2). One possible reason could be that the wells are located near agricultural lands. An additional possibility, which is not exclusive of the first, relates to sampling depth. If the source of $\mathrm{ClO}_{4}{ }^{-}$is at or near the surface, then infiltrating $\mathrm{ClO}_{4}{ }^{-}$would be less likely to be diluted in the water-table monitoring wells. These monitoring wells have shallow screen intervals and low mixing potential compared with other well types.

Of the 1030 wells sampled, 886 (86\%) were within $1.6 \mathrm{~km}$ of agricultural lands. 489 (55\%) of these wells had detectable $\mathrm{ClO}_{4}^{-}(>0.1 \mathrm{ppb})$. Of the $139(13.5 \%)$ wells located in rangeland that was at least $1.6 \mathrm{~km}$ away from the nearest agricultural land, 79 (58\%) wells had detectable $\mathrm{ClO}_{4}{ }^{-}(>0.1$
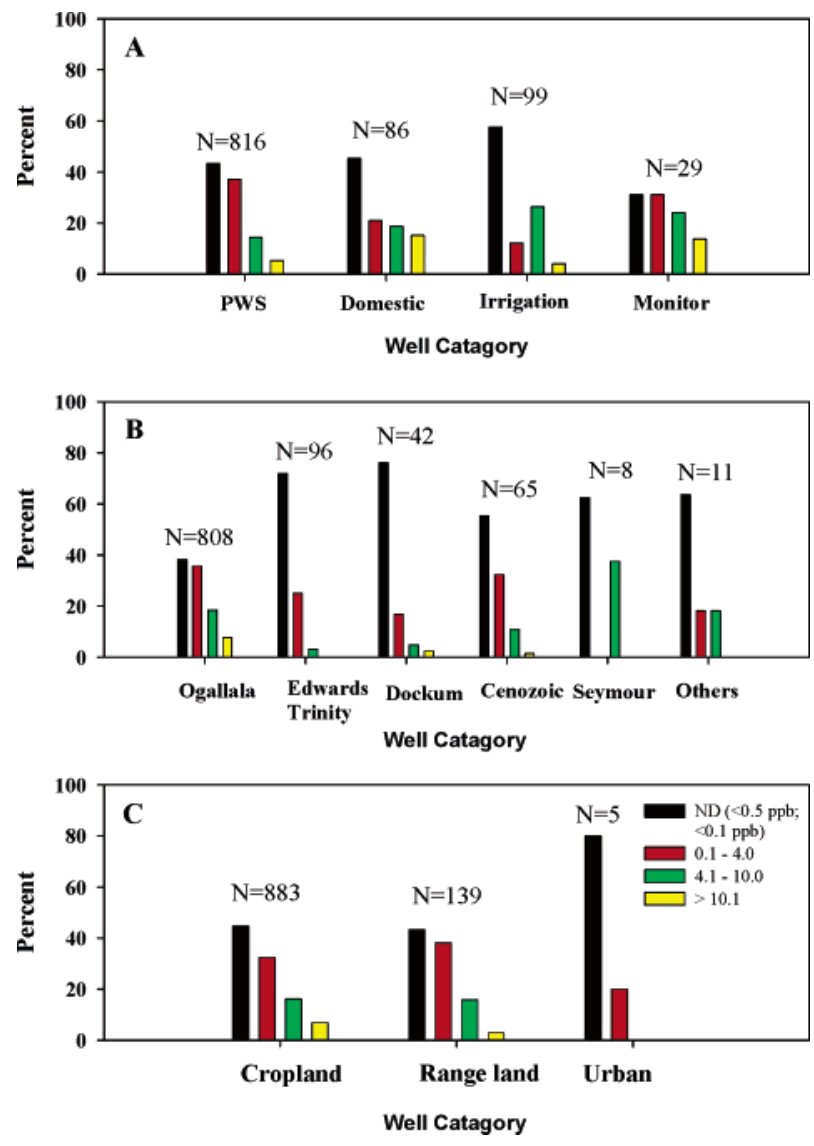

FIGURE 2. Fraction of wells containing $\mathrm{ClO}_{4}{ }^{-}$in specific concentration ranges by (A) well type (B) aquifer (C) land use. (Data include 115 PWS and domestic wells reanalyzed at a lower detection limit of $0.1 \mathrm{ppb})$.

$\mathrm{ppb}$ (Figure 2). It appears that the source of the $\mathrm{ClO}_{4}{ }^{-}$is most likely distributed over the surface and unlikely to be related to point anthropogenic sources, given the uniform distribution of $\mathrm{ClO}_{4}^{-}$between different land uses and its widespread occurrence in most aquifers.

Relation Between Perchlorate, Depth to Water, and Saturated Thickness. Relations between the saturated thickness and depth to water (unsaturated zone thickness) in the Ogallala aquifer with respect to $\mathrm{ClO}_{4}{ }^{-}$concentrations were evaluated. The saturated thickness and aquifer thickness data for the Ogallala aquifer were obtained from the USGS (29). The depth to groundwater was estimated as the difference between water-table and land surface altitudes. Only wells completed in the Ogallala aquifer were considered because sufficient aquifer data were not available for wells in the other aquifers. In addition to this analysis, the results from USGS nested wells and TTU well clusters were available for vertically discrete data.

Perchlorate, TDS, $\mathrm{SO}_{4}{ }^{-2}, \mathrm{Cl}^{-}, \mathrm{Br}^{-}$, and $\mathrm{NO}_{3}{ }^{-}$concentrations in the Ogallala aquifer are inversely correlated with depth to the water table from the ground surface $\left(\mathrm{ClO}_{4}{ }^{-} ; r=-0.62\right.$, $\mathrm{p}<0.0001)$ and saturated thickness $\left(\mathrm{ClO}_{4}{ }^{-} ; r=-0.41, \mathrm{p}<\right.$ 0.0001) (see Figures B and C, Supporting Information). Saturated thickness is variable over the study area, although the northeastern part of the study area has much greater saturated thicknesses (29). The correlation between depth to water and $\mathrm{ClO}_{4}{ }^{-}$concentration may be related to the time of travel through the unsaturated zone and the relation between $\mathrm{ClO}_{4}{ }^{-}$concentration and saturated thickness may represent dilution of $\mathrm{ClO}_{4}{ }^{-}$in the saturated zone. Downward migration could be enhanced in irrigated agricultural or other 
areas of focused recharge, such as playas. If the source of $\mathrm{ClO}_{4}{ }^{-}$is from the land surface, then samples collected from wells that are screened over large or deep intervals might be expected to have lower concentrations of $\mathrm{ClO}_{4}{ }^{-}$than those that are screened near the water table. Total mass of $\mathrm{ClO}_{4}{ }^{-}$ in the saturated zone of only the Ogallala portion of the study area was estimated to be $1.60 \times 10^{6} \mathrm{~kg}$ (see Supporting Information).

Relation of Perchlorate to Other Water Quality Parameters. Water quality parameters measured only in the Ogallala aquifer were tested for correlation with $\mathrm{ClO}_{4}{ }^{-}$concentration (see Table A, Supporting Information). This analysis included data from 620 samples completed in the Ogallala aquifer and 65 wells from the first subset for which $\mathrm{IO}_{3}{ }^{-}$was also evaluated. Data from other aquifers were not considered because insufficient data were available. $\mathrm{SO}_{4}{ }^{2-}, \mathrm{Cl}^{-}$, and $\mathrm{Br}^{-}$ had correlation coefficients exceeding 0.5 , while $\mathrm{F}^{-}$and $\mathrm{NO}_{3}{ }^{-}$ had correlation coefficients less than 0.3. Cations had generally lower correlation coefficients $(\mathrm{r}<0.5)$; $\mathrm{Sr}^{2+}$ and $\mathrm{K}^{+}$ had the highest correlation coefficients $(r=0.47$ and $r=0.42$ respectively), while $\mathrm{Na}^{+}, \mathrm{Ca}^{2+}$, and $\mathrm{Mg}^{2+}$ were less than 0.4 . For the smaller subset, $\mathrm{IO}_{3}{ }^{-}$and $\mathrm{SO}_{4}{ }^{2-}$ had the highest correlation coefficients ( $r=0.66$ and 0.67 , respectively) with respect to $\mathrm{ClO}_{4}^{-}$. Chemical species that had relatively large correlation coefficients in the larger dataset also had higher correlation coefficients in the smaller dataset. The high positive correlation of $\mathrm{ClO}_{4}{ }^{-}$with $\mathrm{IO}_{3}{ }^{-}$is consistent with the hypothesis of atmospheric origin for $\mathrm{ClO}_{4}{ }^{-}$in the study area $(9,12)$ as the only major source of $\mathrm{IO}_{3}{ }^{-}$is atmospheric deposition. Positive correlations with TDS, anions, and cations could indicate general flushing of salts from the land surface or unsaturated zone to the water table by precipitation-irrigation-evaporation cycles.

Vertical Distribution of Perchlorate. The vertical distribution of $\mathrm{ClO}_{4}{ }^{-}$was evaluated in five well clusters designed to sample from discrete vertical intervals. Generally, a decrease in $\mathrm{ClO}_{4}^{-}$concentration with increase in depth in the Ogallala aquifer was observed at each site (Table 1). The nested well cluster in Martin County was installed on land that has not been in agricultural use since the 1980s. This location is also near a large PWS well field with relatively high ( $\sim 20 \mathrm{ppb})$ local concentrations of $\mathrm{ClO}_{4}{ }^{-}$. All three wells in the cluster were completed in the Ogallala formation (Table 1). Tritium values for water from the middle and lower screen intervals indicated the deeper water infiltrated the aquifer before the early 1950s, while water from the shallowest screen interval reflects infiltration since the 1950s (modern water). $\mathrm{ClO}_{4}{ }^{-}$concentration was highest in the shallowest well and was stable over a two year period with the maximum observed change less than $10 \% . \mathrm{NO}_{3}{ }^{-}$, TDS, and $\mathrm{SO}_{4}{ }^{2-}$ had similar decreases in concentration with depth, while $\mathrm{Cl}^{-}$and $\mathrm{Br}^{-}$ had increases in concentration with depth. It should be noted that irrigated agriculture started as early as 1930 in this area, which would represent 20 years of irrigation prior to 1950.

The nested well cluster in Gaines County sampled water from the Ogallala, Edwards Trinity (High Plains) (ETHP), and Dockum groups (Table 1). The depth to water in this location was less than $10 \mathrm{~m}$. These wells were installed at a location that was removed from agricultural use in the 1990s, but was previously in agricultural use since the 1930s. Perchlorate concentrations were the highest of any samples collected in the study area $(179,111$, and $97.9 \mathrm{ppb}$ for the descending screen intervals, respectively). Tritium values (1.5 TU to 3.3 $\mathrm{TU}$ ) indicate the water at this site was mixed and has been influenced by modern water infiltration since the 1950s. Intense irrigation can cause vertical mixing from large areas $(30,31)$.

Two wells were installed in Muleshoe National Wildlife Refuge with a relatively shallow water table of $16 \mathrm{~m}$. The upper well screen (20.1-26.2 m) spanned both the Ogallala and ETHP aquifers (Table 1). The lower screen sampled from the ETHP aquifer. Tritium data indicated neither well has been influenced by infiltration of modern water. Water from the upper-screened interval contained $\mathrm{ClO}_{4}^{-}(1.2 \mathrm{ppb})$ while the lower screened interval did not contain $\mathrm{ClO}_{4}{ }^{-}$above 0.1 $\mathrm{ppb}$. Water from the deeper interval was anaerobic $(\mathrm{DO}<$ $0.5 \mathrm{mg} / \mathrm{L}$ ), and $\mathrm{ClO}_{4}^{-}$would not be stable under these conditions.

The USGS nested well clusters were installed in zones of greater saturated thickness and were in areas of larger depths to water than the TTU well clusters (Table 1). Water quality in these wells has been previously characterized and discussed (30). Perchlorate was not detected $(<0.5 \mathrm{ppb})$ in any of the Castro County nested wells, even though the top screen interval was affected by agricultural activities. Low DO in water at this site can lead to $\mathrm{ClO}_{4}{ }^{-}$being used as an alternate electron acceptor (32).

In Hale County, $\mathrm{ClO}_{4}{ }^{-}$concentration was highest (6 ppb) in the uppermost (water-table) screen interval and a trace $(0.2 \mathrm{ppb})$ was detected in the intermediate deep interval (from 118 to $121 \mathrm{~m}$ below land surface). Perchlorate was not detected above $0.5 \mathrm{ppb}$ in the remaining two well screens. Water from the shallow interval was affected by infiltration since the 1950s, while deeper water was $>1000$ years old (30). Water from the top interval was generally higher in most major anion and cation concentrations, which was attributed to agricultural influences. Possible explanations for the elevated presence of $\mathrm{ClO}_{4}{ }^{-}$in the top interval include agricultural activity as a source, or the flushing of naturally occurring $\mathrm{ClO}_{4}^{-}$from the unsaturated zone.

Potential Sources of Perchlorate. Data supporting the hypothesis that $\mathrm{ClO}_{4}{ }^{-}$has a surface origin include the vertical distribution of $\mathrm{ClO}_{4}{ }^{-}$in saturated vertical transects (Table 1), the high correlation between $\mathrm{ClO}_{4}{ }^{-}$and atmospherically derived $\mathrm{IO}_{3}{ }^{-}$, independence of $\mathrm{ClO}_{4}{ }^{-}$concentration relative to aquifers, and the relation between $\mathrm{ClO}_{4}{ }^{-}$occurrence and depth to the water-table. In addition, $\mathrm{ClO}_{4}{ }^{-}$has been found in unsaturated sediments from the clustered well sites (33).

A number of potential sources can be excluded from consideration as the primary $\mathrm{ClO}_{4}^{-}$source in the study area. Formerly used defense sites (FUDS) are not a likely source because of their limited distribution in the study area as well as lack of evidence for the widespread use of $\mathrm{ClO}_{4}^{-}$containing products at these facilities (15). Slow groundwater velocities $(<0.3 \mathrm{~m} / \mathrm{d})$ in the study area (34) make it difficult for point sources to account for the widespread distribution in groundwater, as insufficient time is available for widespread transport and dispersion of anthropogenically derived $\mathrm{ClO}_{4}{ }^{-}$. Flares and fireworks, while potentially a more widespread source, are excluded, as the mass required is unreasonable, and the occurrence in areas of extremely limited populations also makes these unlikely sources.

The oil and gas industry is widespread across the study area. Locations of oil and gas wells do not appear to have any relation to $\mathrm{ClO}_{4}^{-}$occurrence (Figure 1D). Insufficient data are available to estimate the total mass of $\mathrm{ClO}_{4}{ }^{-}$potentially derived from seismic exploration without information on blast locations, type of explosive, residual $\mathrm{ClO}_{4}{ }^{-}$(post blast), and placement depth. However, this is not a likely source as $\mathrm{ClO}_{4}^{-}$is much more widely distributed than oil and gas activities.

$\mathrm{ClO}_{4}^{-}$is not a primary chemical for agricultural purposes. However, $\mathrm{ClO}_{4}^{-}$can exist as an impurity or byproduct in two common agricultural products, mined nitrate fertilizers primarily from $\mathrm{Chile}$ and $\mathrm{ClO}_{3}{ }^{-}$defoliants. Assuming chlorate was used as the only defoliant for the time period from 1930 to 2000 on the maximum area of recorded cotton cultivation (11 $500 \mathrm{~km}^{2}$ ), $3.9 \times 10^{8} \mathrm{~kg}$ of $\mathrm{ClO}_{3}{ }^{-}$could have been applied in the study area (see Supporting Information for assumptions and calculations). A measured concentration of $\mathrm{ClO}_{4}{ }^{-}{\mathrm{in} \mathrm{ClO}_{3}}^{-}$ 
defoliant ( $24 \mathrm{mg} / \mathrm{kg}$ ) would account for $1.7 \%$ of the estimated $\mathrm{ClO}_{4}{ }^{-}$mass in the study area. Even given the extreme time period assumed (chlorates have not been a preferred defoliant for over 20 years), maximum acreage applied, and sole use of chlorate defoliants, it would require greater than $50 \times$ the measured concentration to account for the estimated mass of $\mathrm{ClO}_{4}{ }^{-}$in the saturated zone alone. It is possible that historical use of chlorate herbicides have contributed to the occurrence of $\mathrm{ClO}_{4}{ }^{-}$in the study area but it is highly unlikely that they are the primary source of $\mathrm{ClO}_{4}{ }^{-}$, given the required time period, area affected, and $\mathrm{ClO}_{4}^{-}$application rates required.

The amount of Chilean nitrate imported into the United States from 1938 to 1968 , the time period with the best historical information, was $1.61 \times 10^{10}$ kilograms (35). This amount includes Chilean nitrate used in the defense industry, local industrial use, and fertilizers. Records of Chilean fertilizer use in Texas were not identified; however, for comparison the amount of Chilean nitrate used from 1923 to 1998 in California, which has roughly the same area of improved farmland as the study area, was $4.77 \times 10^{8} \mathrm{~kg}$ (36). Assuming a measured concentration of $0.1 \% \mathrm{ClO}_{4}{ }^{-}$in the fertilizer (37), and taking the calculated mass of $\mathrm{ClO}_{4}{ }^{-}$in the saturated zone of the Ogallala, a conservative estimate of $1.60 \times 10^{9}$ $\mathrm{kg}$ of the Chilean nitrate fertilizer is required if considered as the sole source of $\mathrm{ClO}_{4}{ }^{-}$in the Ogallala aquifer. This value would require $10 \%$ of the entire Chilean nitrate imported into United States from 1938 to 1968 to have been applied over the Ogallala aquifer portion of the study area alone. If the mass in the other saturated parts of the study area and the mass in the overlying unsaturated sediments of the study area were to be included, the required percentage of imported Chilean nitrate fertilizer use would increase. Given that a large fraction of Chilean nitrate imported (35) was used for manufacturing explosives during the World War II and California was reported to use only $4.77 \times 10^{8} \mathrm{~kg}$ (30\% of the value derived above) of Chilean nitrate fertilizer from 1923 to 1998 , it is unlikely to be the sole or primary source. In addition, the presence of $\mathrm{ClO}_{4}{ }^{-}$in regions where no cultivated agriculture was practiced, and the lack of correlation between $\mathrm{NO}_{3}{ }^{-}$and $\mathrm{ClO}_{4}{ }^{-}$in groundwater in the study area support the conclusion that agricultural compounds are not the primary sources of $\mathrm{ClO}_{4}^{-}$.

The known occurrence of $\mathrm{ClO}_{4}{ }^{-}$in Chilean nitrate deposits (6), evaporites in North America (14), and in precipitation in the study area (12) coupled with the understanding that the Chilean deposits are of atmospheric origin (8), indicate that some $\mathrm{ClO}_{4}{ }^{-}$occurrences can be naturally derived. Using an average $\mathrm{ClO}_{4}{ }^{-}$concentration of $0.2 \mathrm{ppb}(n=22)$ in precipitation measured for the study area over a 14 month period (12) and assuming an average yearly precipitation of $0.5 \mathrm{~m}$ (range 0.35 to $0.65 \mathrm{~m}$ ) would result in an average $\mathrm{ClO}_{4}{ }^{-}$ deposition of $0.1 \mathrm{mg} / \mathrm{m}^{2} / \mathrm{yr}$. Considering only the $\mathrm{ClO}_{4}{ }^{-}$in the saturated zone in the Ogallala aquifer, 156 years would be required to generate the calculated mass. This is well within the accepted accumulation times (2500-10 000 years) for salts and groundwater in the high plains region (38). Even if the average $\mathrm{ClO}_{4}{ }^{-}$concentration in precipitation is an order of magnitude lower, deposition from precipitation is still a reasonable source. It should be noted that this calculation does not include potential dry deposition which would further shorten the estimated times required nor does it include $\mathrm{ClO}_{4}{ }^{-}$transformed by microbial reduction, plant uptake, or lost to runoff (generally considered negligible for the high plains) which would increase required accumulation times.

An atmospheric origin is also supported by the ratios of $\mathrm{Cl}^{-} / \mathrm{Br}^{-}$(39) and $\mathrm{Cl}^{-} / \mathrm{ClO}_{4}^{-}$(12) in groundwater of the Ogallala which closely track the modern bulk atmospheric ratio line for each ratio (Figure 3). The high correlation of the $\mathrm{Cl}^{-} / \mathrm{Br}^{-}$ ratio and its similarity to the modern bulk atmospheric ratio

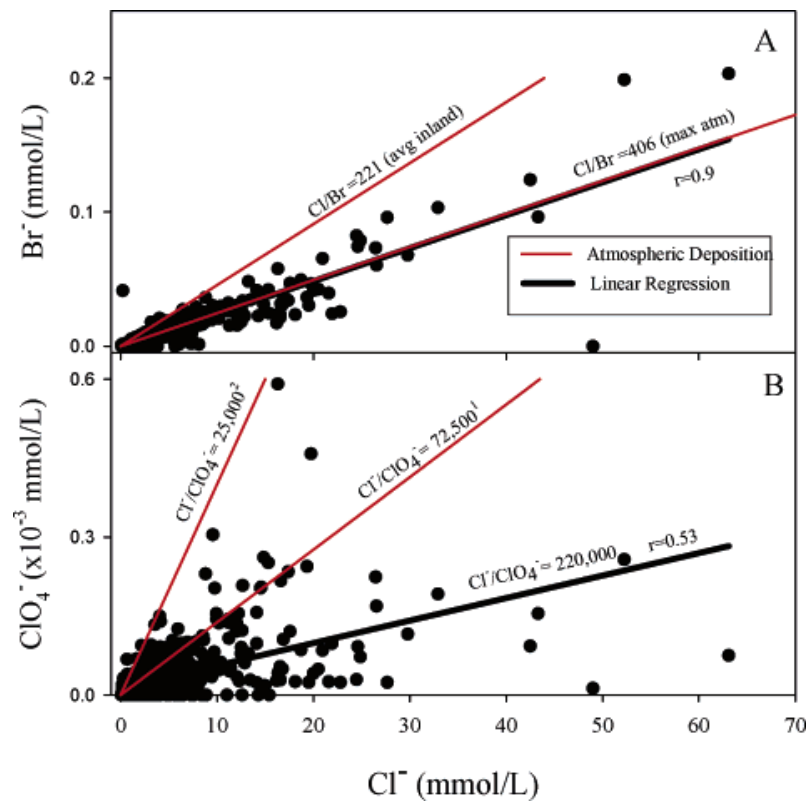

FIGURE 3. (A) $\mathrm{Cl}^{-} / \mathrm{Br}^{-}$ratios in Ogallala aquifer with average inland and maximum coastal atmospheric deposition lines (39); (B) $\mathrm{Cl}^{-}$I $\mathrm{ClO}_{4}{ }^{-}$ratios in 0 gallala aquifer with average atmospheric deposition ratio lines 'Data from Dasgupta et al. (Non detectable $\mathrm{ClO}_{4}{ }^{-}$ concentrations assigned $0.005 \mathrm{ppb}$ ) (12) ${ }^{2}$ Data from Plummer et al. (16).

(39) strongly supports an atmospheric origin of these anions. The $\mathrm{Cl}^{-} / \mathrm{ClO}_{4}{ }^{-}$ratio line shown is certainly much more open to question, but as there is extremely limited data available on $\mathrm{ClO}_{4}^{-}$in wet and dry deposition, the agreement is compelling. The higher ratio reported here $(220000)$ indicates that significant loss of $\mathrm{ClO}_{4}^{-}$has occurred as $\mathrm{Cl}^{-}$is considered conserved although non atmospheric sources of $\mathrm{Cl}^{-}$are possible. The average $\mathrm{Cl}^{-} / \mathrm{ClO}_{4}{ }^{-}$ratio as well as almost all individual ratios for this study is also higher than reported by Plummer et al. (17) (25 000) for New Mexico Pleistocene and Holocene groundwater. The concentration range of both $\mathrm{Cl}^{-}$and $\mathrm{ClO}_{4}^{-}$reported here is also much greater and not likely due to simple evaporative concentration but rather flushing of atmospherically deposited salt species into groundwater due to either climate change or more likely modern irrigation practices and possibly additional evaporative concentration due to multiple irrigation and return flow cycles. As $\mathrm{ClO}_{4}{ }^{-}$can be used as an electron acceptor by bacteria and accumulated by plants, it is unlikely to be completely conserved in the soil, and so the higher ratio reported in this study is not unexpected. Other evidence supporting atmospheric deposition includes the strong correlation between $\mathrm{IO}_{3}{ }^{-}$and $\mathrm{ClO}_{4}{ }^{-}$, the extremely large area affected by $\mathrm{ClO}_{4}^{-}$, and the presence of $\mathrm{ClO}_{4}{ }^{-}$in water older than 1950.

A definitive source for the $\mathrm{ClO}_{4}{ }^{-}$cannot be determined from the available data and it is likely that multiple sources contribute to the occurrence of $\mathrm{ClO}_{4}{ }^{-}$. The data indicate that the majority of the $\mathrm{ClO}_{4}{ }^{-}$could result from atmospheric deposition. Variations in concentration for different parts of the study area may be explained by complex relations between the depth to water, saturated thickness, and land use. Recent advances in isotope analysis may be able to identify the source(s) of $\mathrm{ClO}_{4}^{-}$; however, isotopic analyses done for 2 wells in the study area were inconclusive (40). Results from this study highlight the need for future studies of land use changes in arid and semiarid areas in relation to the impact on groundwater quality. 


\section{Acknowledgments}

This study was supported by the Texas Commission on Environmental Quality. The manuscript was improved following technical reviews from Steve Kalkhoff and Kent Becher, USGS, and three anonymous reviewers. We also acknowledge the High Plains Underground Water Conservation District No.1 for allowing access to their samples as well as the cooperation of all the Public Water systems Sampled.

\section{Supporting Information Available}

Additional information available on the aquifers in the study area, details of mass calculations, and Table A containing the individual correlation coefficients of $\mathrm{ClO}_{4}{ }^{-}$with other major species. In addition, three figures are available including details of the study area, major anions vs depth to water and saturated thickness, and required $\mathrm{ClO}_{4}{ }^{-}$to account for $\mathrm{ClO}_{3}{ }^{-}$. This material is available free of charge via the Internet at http://pubs.acs.org.

\section{Literature Cited}

(1) Motzer, W. E. Perchlorate: Problems, detection, and solutions. Environ. Forensics. 2001, 2, 301-311.

(2) Jackson, W. A.; Joseph, P. C.; Patil, L. B.; Tan, K.; Smith, P. N.; Yu, L.; Anderson, T. A. Perchlorate accumulation in forage and edible vegetation. J. Agri. Food. Chem. 2005a, 53, 374-382.

(3) FDA. Exploratory Data on Perchlorate in Food. Accessed March 2005 from: http://www.cfsan.fda.gov/ dms/clo4data.html.

(4) Kirk, A. B.; Martinelango, P. K.; Tian, K.; Dutta, A.; Smith, E. E.; Dasgupta, P. K. Perchlorate and iodide in dairy and breast milk. Environ. Sci. Technol. 2005, 39, 1569-1575.

(5) Wolff, J. Perchlorate and the thyroid gland. Pharmocol. Rev. 1998, 50, 89-105.

(6) Ericksen, G. E. The Chilean nitrate deposit. Am. Sci. 1983, 71, 366-374.

(7) Walvoord, M. A.; Phillips, F. M.; Stonestrom, D. A.; Evans, R. D.; Hartsough, P. C.; Newman, B. D.; Striegl, R. G. A reservoir of nitrate beneath desert soils. Science 2003, 302, 1021-1024.

(8) Michalski, G., Bohlke, J. K.; Thiemens, M. Long-term atmospheric deposition as the source of nitrate and other salts in the Atacama Desert, Chile: New evidence from mass-independent oxygen isotopic compositions. Geochim. Cosmochim. Acta 2004, 68, 4023-4038.

(9) Vogt, R. Iodine compounds in the atmosphere. In Reactive halogen compounds in the atmosphere; Fabian, P., Singh, O. N., Eds.; Springer-Verlag: Berlin Heidelberg, 1999; pp 113-128.

(10) Bao, H.; Gu, B. Natural perchlorate has a unique isotope signature. Environ. Sci. Technol. 2004, 38, 5073-5077.

(11) Murphy, D. M.; Thomson, D. S. Halogen ions and NO+ in the mass spectra of aerosols in the upper troposphere and lower stratosphere. Geophys. Res. Lett. 2000, 27, 3217-3220.

(12) Dasgupta, P. K.; Martinelango, P. K.; Jackson, W. A.; Anderson, T.A.; Tian, K.; Tock, R. W.; Rajagopalan, S. The origin of naturally occurring perchlorate: the role of atmospheric processes. Environ. Sci. Technol. 2005, 39, 1569-1575.

(13) Ericksen, G. E.; Hosterman, J. W.; St. Amand., P. Chemistry, mineralogy and origin of the clay-hill nitrate deposits, Amargosa River Valley, Death Valley region, California, U.S.A. Chem. Geol. 1988, 67, 85-102.

(14) Orris, G. J.; Harvey, G. J.; Tsui, D. T.; Eldridge, J. E. Preliminary analyses for perchlorate in selected natural materials and their derivative products, USGS Open File Report 03-314; USGS, U.S. Government Printing Office: Washington, DC, 2003.

(15) Jackson, W. A.; Anandam, S.-K.; Anderson, T.; Lehman, T.; Rainwater, K.; Rajagopalan, S.; Ridley, M. K.; Tock, R. Perchlorate occurrence in the Texas southern high plains aquifer system. Ground Water Monitor. Remed. 2005b, 25, 137-149.

(16) Snyder, S. A.; Vanderford, B. J.; Rexing, D. J. Trace analysis of bromate, chlorate, iodate, and perchlorate in natural and bottled waters. Environ. Sci. Technol. 2005, 39, 4586-4593.

(17) Plummer, L. N.; Bohlke, J. K.; Doughten, M. W. Perchlorate in Pleistocene and Holocene groundwater in North-Central New Mexico. Environ. Sci. Technol. 2005, 39, 4586-4593.

(18) Texas Counties-Census 2000: Viewing data for all age groups. http://www.county.org/resources/countydata/Bin/pl94-171.ht$\mathrm{ml}$.
(19) Texas State Library and Archive Commission: About Texaspopulation, Texas cities http://www.tsl.state.tx.us/ref/abouttx/ population2.html.

(20) Geostat Center Collections: National Land Cover Data. http:// fisher.lib.virginia.edu/collections/gis/nlcd/.

(21) Bliss, N. B. Cropland by County since 1850 and Population since 1790: A Record of Settlement and Agricultural Disturbance to the Land. http://landcover.usgs.gov/cropland/index.asp.

(22) Railroad Commission of Texas. GIS coverages related to oil and gas activities in Fifty Two Counties in Northern Texas; Texas Railroad Commission: Austin, TX, 2003.

(23) Ashworth, J. B.; Hopkins, J. Aquifers of Texas. Texas Water Development Board, Report 345; 1995; p 69.

(24) Ryder, P. D. Groundwater Atlas of the United States; Oklahoma, Texas. U.S. Geological Survey Hydrologic Investigations Atlas HA-730 E; U.S. Government Printing Office: Washington, DC, 1996.

(25) Boghici, R. Changes in Groundwater Conditions in Parts of Trans-Pecos Texas 1988-1998, Texas Water Development Board, Report 348; 1999.

(26) Hautman, D. P.; Munch, D. J.; Eaton, A. D.; Haghani, A. W. Method 314.0 Determination of Perchlorate in Drinking Water Using Ion Chromatography, Revision 1.0., EPA 815-B-99-003; U.S. Environmental Protection Agency: Cincinnati, OH, 1999; p 49.

(27) Thatcher, L. L.; Janzer, V. J.; Edwards, K. W. Methods for determination of radioactive substances in water and fluvial sediments: U.S. Geological Survey Techniques of Water-Resources Investigations, book 5, Chapter A5; U.S. Government Printing Office: Washington, DC, 1977; p 95.

(28) Tian, K.; Canas, J. E.; Dasgupta, P. K.; Anderson, T. A. Preconcentration/preelution ion chromatography for the determination of perchlorate in complex samples. Talanta 2005, 65, 750755.

(29) Houston, N. A.; Garcia, C. A.; Strom, E. W. Selected hydrogeologic datasets for the Ogallala Aquifer, Texas, USGS Open-File Report 03-296; U.S. Government Printing Office: Washington, DC, 2003.

(30) McMahon, P. B.; Bohlke, J. K.; Lehman, T. M. Vertical gradients in water chemistry and age in the Southern High Plains Aquifer, Texas, 2002, U.S. Geological Survey Scientific Investigations Report 2004-5053; U.S. Government Printing Office: Washington, DC, 2004; p 53.

(31) Bruce, B. W.; Oelsner, G. P. Contrasting water quality from paired domestic/ community supply wells, central High Plains. J. Am. Water Res. Association. 2001, 37(5), 1389-1403.

(32) Cox, E. E.; Edwards, E.; Neville, S. In Situ bioremediation of perchlorate in groundwater. In Perchlorate in the Environment; Urbansky, E. T., Ed.; Kluwer Academic. Plenum Pub: New York, 2000.

(33) Rajagopalan, S. Distribution and source evaluation of perchlorate in arid and semi-arid regions, Doctoral Dissertation, Texas Tech University, Lubbock, Texas, 2005.

(34) Fetter, C. W. Applied Hydrogeology, Fourth Edition; Prentice Hall: New Jersey, 2001.

(35) USGS. Bureau of Mines Minerals Yearbook (1932-1993); U.S. Government Printing Office: Washington, DC.

(36) Council on Water Quality: Facts about perchlorate. http:// www.councilonwaterquality.org/know/qa_basics.html.

(37) Urbansky, E. T.; Brown, S.; Magnuson, M.; Kelly, C. Perchlorate levels in samples of sodium nitrate fertilizer derived from Chilean caliche. Environ. Pollut. 2001, 112, 299-302.

(38) Scanlon, B. R.; Goldsmith, R. S. Field study of spatial variability in unsaturated flow beneath and adjacent to playas. Water Resour. Res. 1997, 33 (10), 2239-2252.

(39) Davis, S. N.; Whittemore, D. O.; Fabryka-Martin, J. Uses of chloride/bromide ratios in studies of potable water. Ground Water 1998, 36, 338-350.

(40) Bohlke, J. K.; Sturchio, N. C.; Baohua, G.; Horita, J.; Brown, G. M.; Jackson, W. A.; Batista, J.; Hatzinger, P. B. Perchlorate isotope forensics. Anal. Chem. 2005, 77(23), 7838-7842.

Received for review October 28, 2005. Revised manuscript received February 27, 2006. Accepted March 10, 2006.

ES052155I 